\title{
14. PROGRESSIVE CARBONATE DIAGENESIS AT DEEP SEA DRILLING SITES 206, 207, 208, AND 210 IN THE SOUTHWEST PACIFIC AND ITS RELATIONSHIP TO SEDIMENT PHYSICAL PROPERTIES AND SEISMIC REFLECTORS
}

\author{
Gordon H. Packham, Department of Geology and Geophysics, University of Sydney, Sydney, Australia \\ and \\ Gerrit J. van der Lingen, Department of Scientific and Industrial Research, New Zealand \\ Geological Survey, Christchurch, New Zealand
}

\begin{abstract}
The cores taken at Site 206, 207, 208, and 210 show with minor irregularities a stepwise decrease in degree of deformation downwards. The pattern of lithification is similar. The boundaries between creamy and stiff and between stiff and semilithified sediments occur at about the levels of change in the degree of core deformation. The sonic velocities increase slightly with depth to between 200 and 350 meters depending on the site; below this depth the velocities increase more rapidly. The elbow in the velocity-depth curve occurs in stiff sediments where they become crumbly. The bulk density-depth curve shows a step at 250 to 550 meters, depending on the site. This occurs well within the semilithified zone.

Sediments from each of the sites were examined with the scanning electron microscope (SEM), especially those from the semilithified zone. The welding together of grains commences at the top of the semilithified zone. The pore space decreases at the level at which the bulk density increases, and this is about the upper level at which overgrowths of granular calcite are found.

Comparison of the levels at the four sites at which the various features mentioned occur indicate that the diagenesis pattern is independent of the mid-Tertiary regional unconformity found in the southwest Pacific, but appears to be dependent on both the depth and duration of burial.

Seismic reflectors may possibly be correlated with (1) the creamy-stiff boundary or the drop in core deformation at about that depth; (2) the depth where sediments become crumbly in the stiff zone; (3) the stiff-semilithified boundary where grain welding commences; and (4) the depth of inflection of the bulk density curve where porosity decreases and granular calcite overgrowths commence.
\end{abstract}

\section{INTRODUCTION}

This paper examines the interrelationship between the changes in the physical properties, the macroscopic, and the microscopic features of sediments in the cores from Sites 206, 207, 208, and 210. Also the relationship between these changes and the occurrence of seismic reflectors is examined. The sediments to which the greatest attention is paid are the carbonate sediments. These sediments dominate the successions at Sites 206, 207 (above the acid volcanic basement), 208, and the lower part of 210 . In the upper part of 210 there is a succession of distal turbidites with calcareous intercalations. The calcareous successions contain intermixtures of clay and other terrigenous matter.

The water depth at the drill sites and the depths of penetration are as follows:
1) 206 New Caledonia Basin, water depth 3206 meters sediments penetrated 734 meters.

2) 207 Lord Howe Rise, water depth 1399 meters, sediments penetrated 357 meters.

3) 208 Lord Howe Rise, water depth 1555 meters, sediments penetrated 594 meters.

4) 210 Coral Sea Abyssal Plain, water depth 4650 meters, sediment penetrated 711 meters.

Stratigraphic columns for the sites are given in Figure 1. It will be noted that the regional unconformity between the Paleogene and the Neogene sediments occurs at different depths below the mudline. At Site 206 the depth is 612 meters; at Site 207, 142 meters; at Site 208, 488 meters; and at Site 210,540 meters. This variation enables one to see whether there is a time factor involved in the lithification process. 

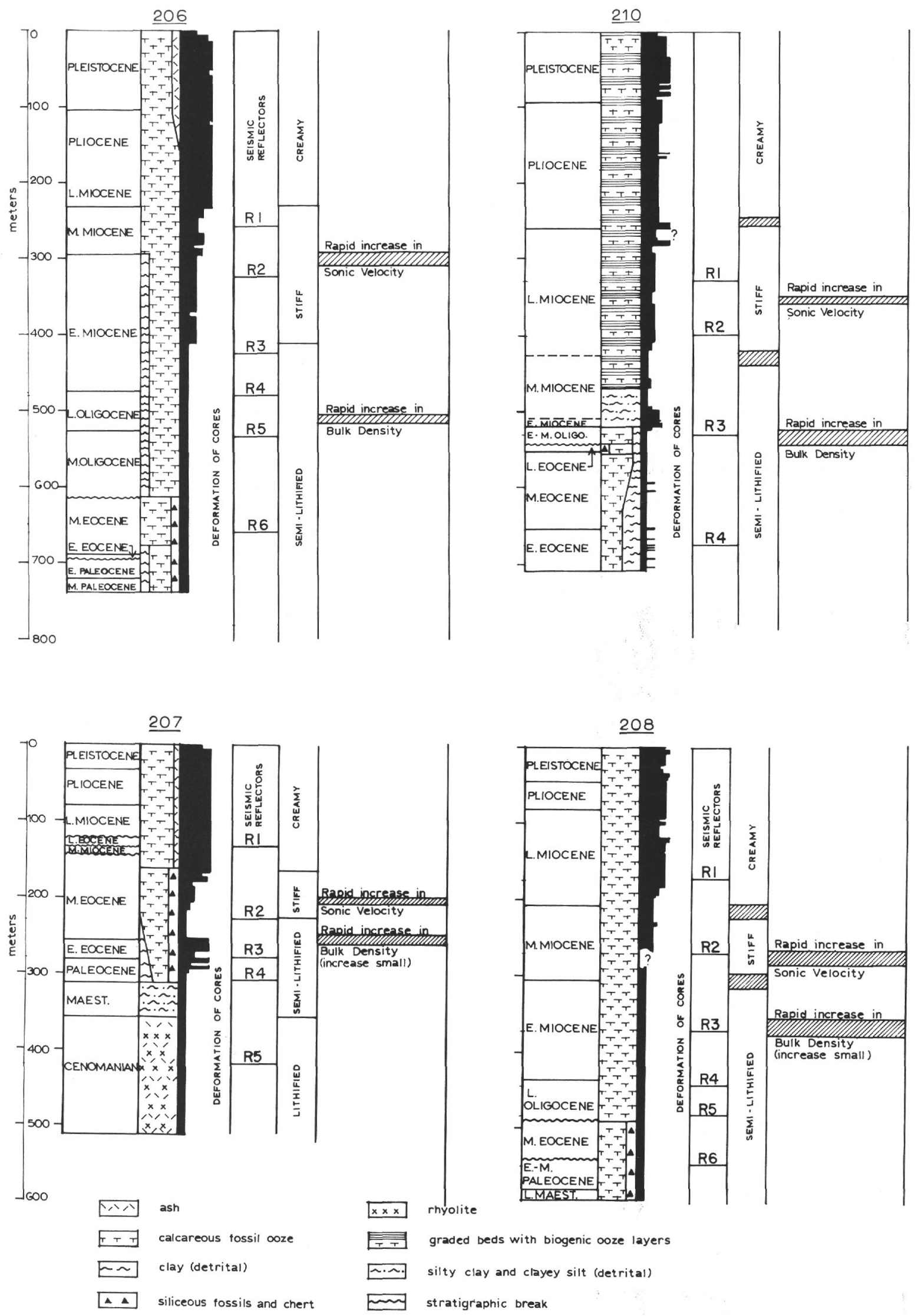

Figure 1. Stratigraphic columns, deformation of cores, seismic reflectors, degree of lithification, changes in sonic velocity, and bulk density at Sites 206, 207, 208, and 210. 
The most complete study of diagenesis in carbonate oozes has been carried out by Schlanger et al. (in press) on sediments at Site 167, on the Magellan Rise, where over 1100 meters of oozes were drilled. The following is a summary of the results obtained by Schlanger et al., given by Davies and Supko (1973):

"Firstly, diagenetic facies coincide with major lithologies as recognized on board ship. Secondly, the physical properties, especially the sonic velocity, show step function changes coincident with diagenetic changes.

"Schlanger et al (in prep) have recognized four distinct diagenetic facies. The top $200 \mathrm{~m}$ of section (Miocene to Recent age) consists of loosely packed coccoliths with well preserved sutures. Break up of the coccoliths contributes prismatic calcite laths to the sediment; these appear as micrite under the light microscope.

"From 200 to 600 meters sub-bottom depth (late Eocene to Oligocene in age), the sediments consist of a very friable, pure white chalk. About 35 percent of the sediment is subhedral calcite crystals. 0.3 to $0.6 \mu$. long. Only local evidence of dissolution is seen. Essentially all the pore water has been squeezed out and maximum contact achieved short of actually crushing the grains.

"Crushed foraminiferan tests were first noticed about $600 \mathrm{~m}$ depth, the depth at which Facies 3 starts. The section from $600 \mathrm{~m}$ to about $830 \mathrm{~m}$ sub-bottom (Coniacian to Middle Eocene) consists of nanno chalks, silicified limestone, and chert. In the nanno chalks, the coccolith remains have been highly etched or coated with granular calcite. Foraminiferan tests have recrystallized and break down to produce micrite.

"Below $825 \mathrm{~m}$ well lithified limestones and cherts are found. These are strongly cemented and the cement crystals are of considerable size."

\section{MACROSCOPIC APPEARANCE OF THE CORES}

In the routine shipboard description of the cores two of the features observed are the degree of consolidation of the sediments and the degree of deformation of the cores. The deformation is the result of the drilling process and hence is an indicator of the plasticity of the sediment.

The definitions of the degree of consolidation of the sediments used in practice are extremely primitive. The softest sediments are described as soupy or creamy depending on whether they flow or are coherent; these sediments can be easily split with a cheese cutter after the coreliner has been cut. At the next stage of lithification the sediments are described as stiff. These can be split with a cheese cutter only if a sawing motion is used. The cut surface is uneven and often has a waxy luster. In the deeper parts of the stiff zone the sediment becomes crumbly. When the sediment can no longer be cut with the cheese cutter, it is described as semilithified. In the upper part of the semilithified zone, there are fragments of rock enclosed in drilling paste formed from its breakdown. Below this the core is in lengths of over $20 \mathrm{~cm}$ with horizontal partings. Below this again, there are small faults and slickensided surfaces inclined at $60^{\circ}$ to $30^{\circ}$. These occur sparsely from this level to the bottoms of the holes under discussion.
The degree of deformation is described on a scale of 1 to 4. On this scale, 1 represents sediments which are undeformed; 2 is used for sediments in which the bedding is gently deformed; 3 indicates that the bedding is strongly deformed but the sedimentary structures are still preserved; and 4 represents cores in which the sedimentary structures have been considerably modified from those in which intermixing of beds has started to take place, through to cores in which the sediments have been completely homogenized. The degree of deformation observed has been plotted in Figure 1.

The degree of lithification and the amount of deformation are closely related in the sites under discussion. The lithification, as Schlanger et al. noted, seems to increase in a stepwise manner. Some reversals in lithification do occur in the cores. For example, at Site 207 between 255 meters and 285 meters the cores contain sediment ranging from soupy to semilithified. From 229 meters to 255 meters the sediments are consistently semilithified. This apparent reversal could possibly be explained by the nature of the drilling process. The oozes in this interval contain chert nodules which have been broken up by the drill; these chert fragments appear then to have ground some sections of the semilithified sediment into a paste. In Figures 1 and 2, two lithification boundaries are plotted, the upper one is the level at which stiff sediments first appear, and the lower one is the upper limit at which sediments are consistently semilithified. It should be noted that these levels are independent of lithology and the regional unconformity. Both of the boundaries are above the regional unconformity at Sites 206, 208, and 210, but both are below at Site 207 where their levels are shallower than in the other sites.

Examination of the plots of the degree of deformation of the sediments (Figure 1) reveals the presence of discontinuities which correspond reasonably closely with the lithification discontinuities. In the lowest zone the deformation is mostly 1 , in the second it is mostly 2 , and in the upper zone is in the range of 3 to 4 . At Site 210, there is an intermediate zone from 185 meters to 290 meters where it is mainly 2 to 3 . The different response to drilling in the sediments at this site is to be expected in this part of the section since it consists of interbedded clays, biogenic oozes, and silts or very fine sands.

\section{SONIC VELOCITY TRENDS}

A plot of the sonic velocities at each of the sites revealed that for the first few hundred meters, the increase of velocity with depth was small; thereafter the increase is much more rapid. This phenomenon is more clearly shown on a plot of the velocity on a linear s cale and the depth on a logarithmic scale. The plots are presented in Figures 3 to 6. A curve of best fit has been determined by eye, and the depth on this curve where the velocities increase rapidly with depth has been read off and plotted in Figures 1 and 2 .

In all cases the elbow in the velocity-depth curve occurs within the zone of stiff sediment and in the zone of moderate deformation. It is again unrelated to the regional 


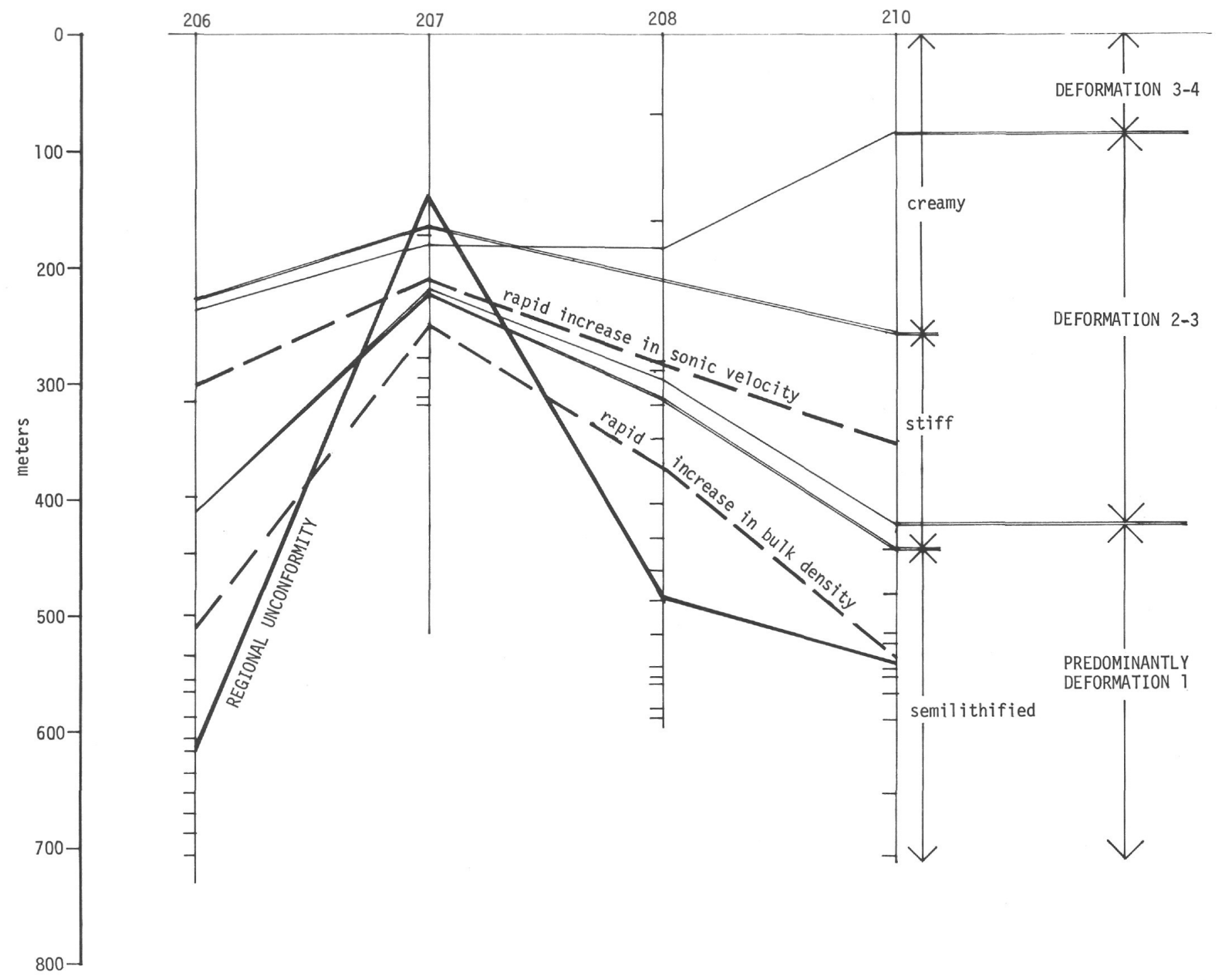

Figure 2. Comparative plot of the main lithification features, physical properties, subbottom depth of the regional unconformity, and locations of the samples examined. The last-mentioned are indicated by horizontal dashes.

unconformity. It is of interest that the form of the curves produced is similar in each case although the wide variation of velocities below the elbow makes the determination of the exact position of the curve problematical. The curves have a form distinctly different from that of Laughton (1954), although they do approximate the form of the mean curve which could be drawn through the plot of depth against average sonic velocities for each core obtained during Phase 1 of the Deep Sea Drilling Project given in Davies and Supko (1973).

At Sites 206 and 210 the elbow in the velocity-depth curve corresponds with the point at which the cores start to be crumbly. A possible explanation is that the pore water has been expelled, the grains have come into contact, and the transmission of sound through the sediment is thus more efficient. At Site 210 this level corresponds reasonably well to the less deformed part of the stiff zone. At Site 206 there is a suggestion of the same phenomenon. Unfortunately, the situation is not so clear at Sites 207 and 208 where the stiff zone is much thinner.

\section{BULK DENSITY TRENDS}

The bulk density of the sediments has been plotted against depth in Figures 3 to 6 . The information plotted is a combination of the GRAPE determinations for creamy to stiff sediments and shipboard determinations of densities of semilithified sediments calculated by weighing a known volume of the sediment. Examination of the plots reveals that in the upper parts of the column there is a small but fairly steady increase of density with depth, then there is a fairly sharp increase with depth from around 1.7 to 1.8 to 1.9 to 2.2 , below which densities only increase slowly with depth. The depths at which the inflection occurs is plotted in Figures 1 and 2.

As with the other features plotted, the point of inflection does not lie on the unconformity plane. It lies well below the elbow of the velocity-depth curve, well within the zone of semilithification. Like the other trends plotted, the depth of the bulk density inflection is not constant, but parallels the other trends plotted. Further the increase of density below the 


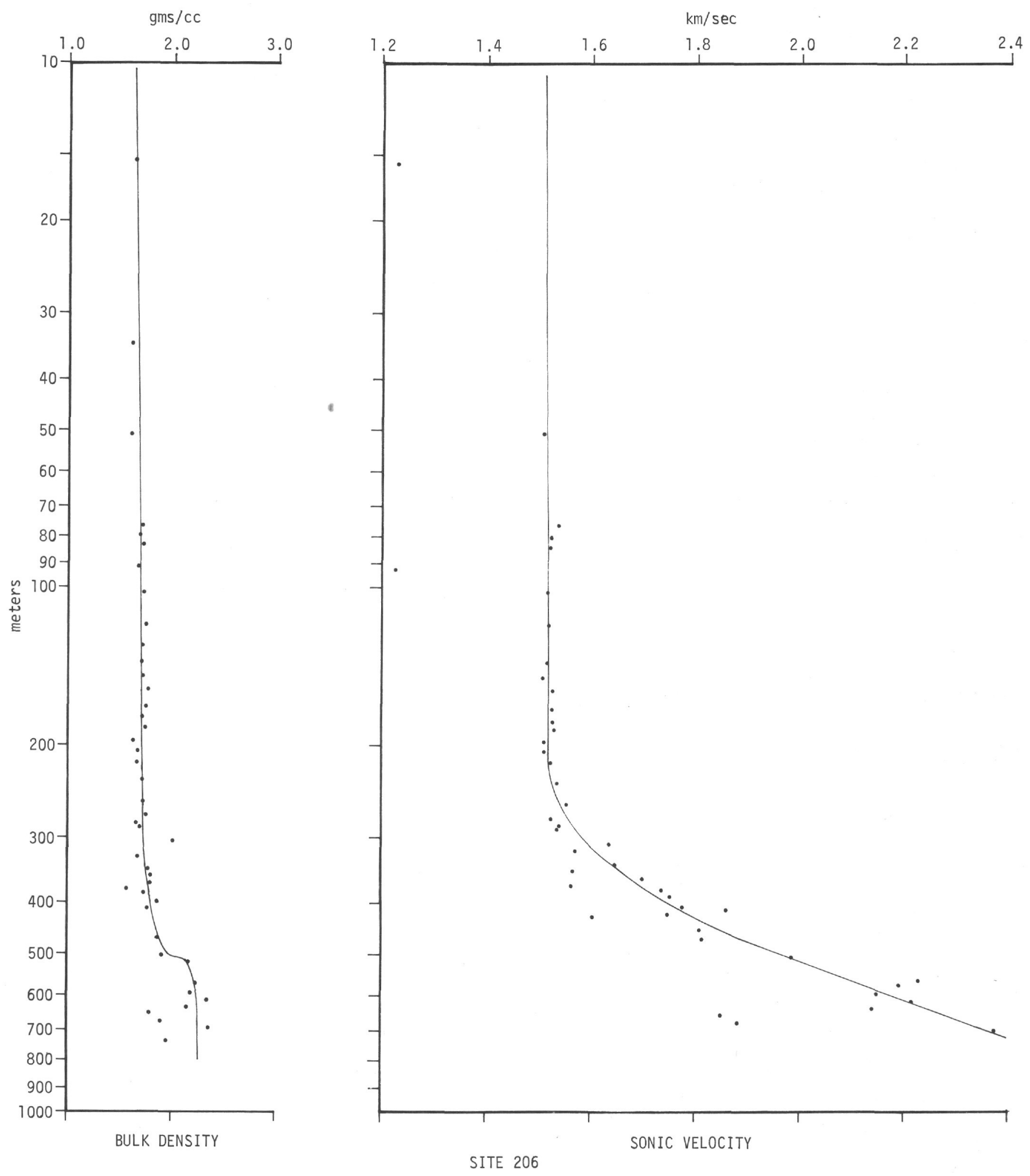

Figure 3. Plot of bulk density and sonic velocity against depth for Site 206.

inflection seems to be related to subbottom depth of the deflection. The greatest densities below the inflection occur at Sites 206 and 210 and lower densities at Sites 207 and 208. The bulk density inflection is a little above the point at which diagonal fractures and slickensides appear at Site
$206(567 \mathrm{~m})$, and at the same level as the appearance of these features at Site $210(520 \mathrm{~m})$ where it is coincident with a lithological change from abyssal clay above to chalk below. Had the beds above been calcareous, the increase in bulk density may have been higher. 
G. H. PACKHAM, G. J. VAN DER LINGEN

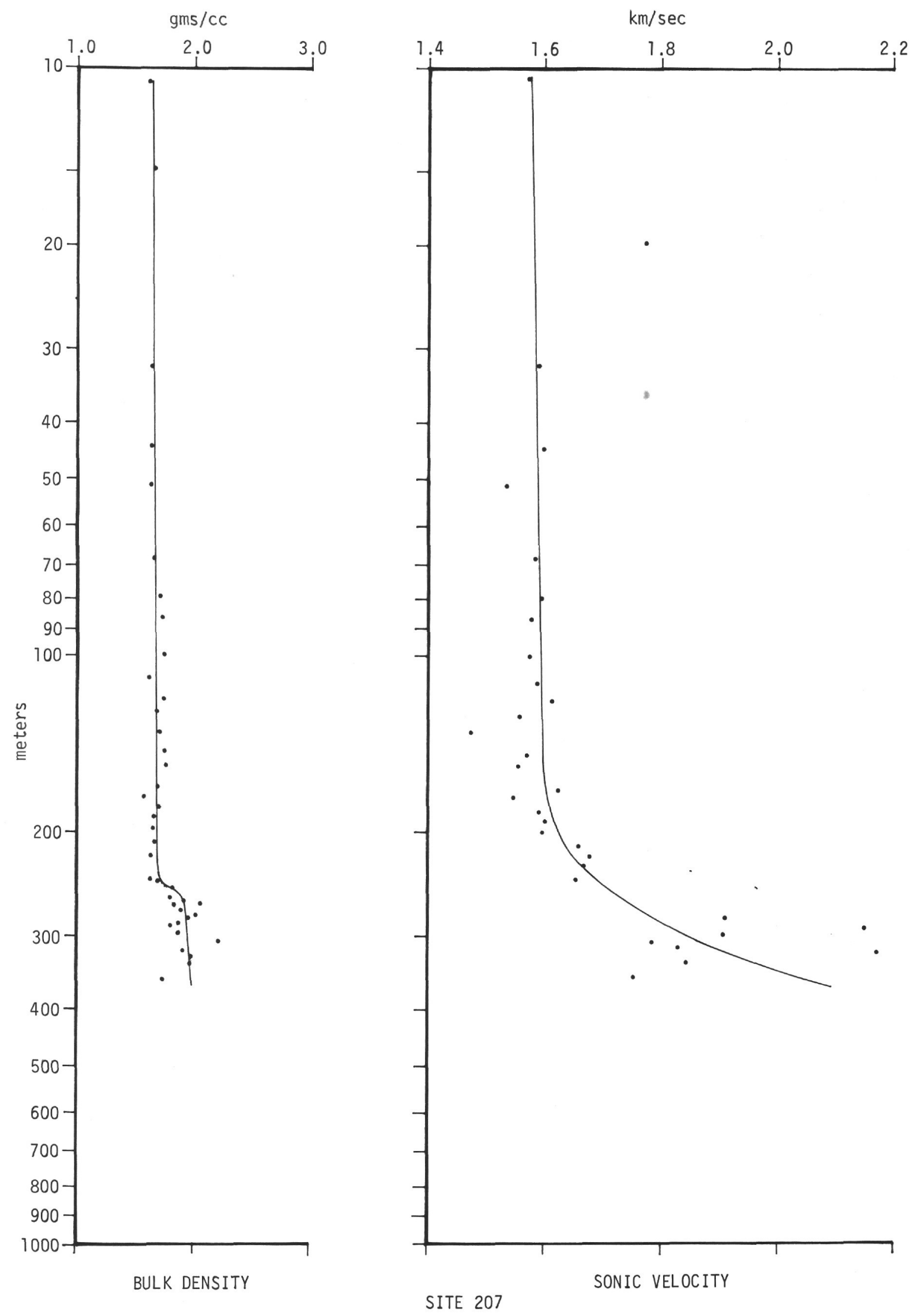

Figure 4. Plot of bulk density and sonic velocity against depth for Site 207. 

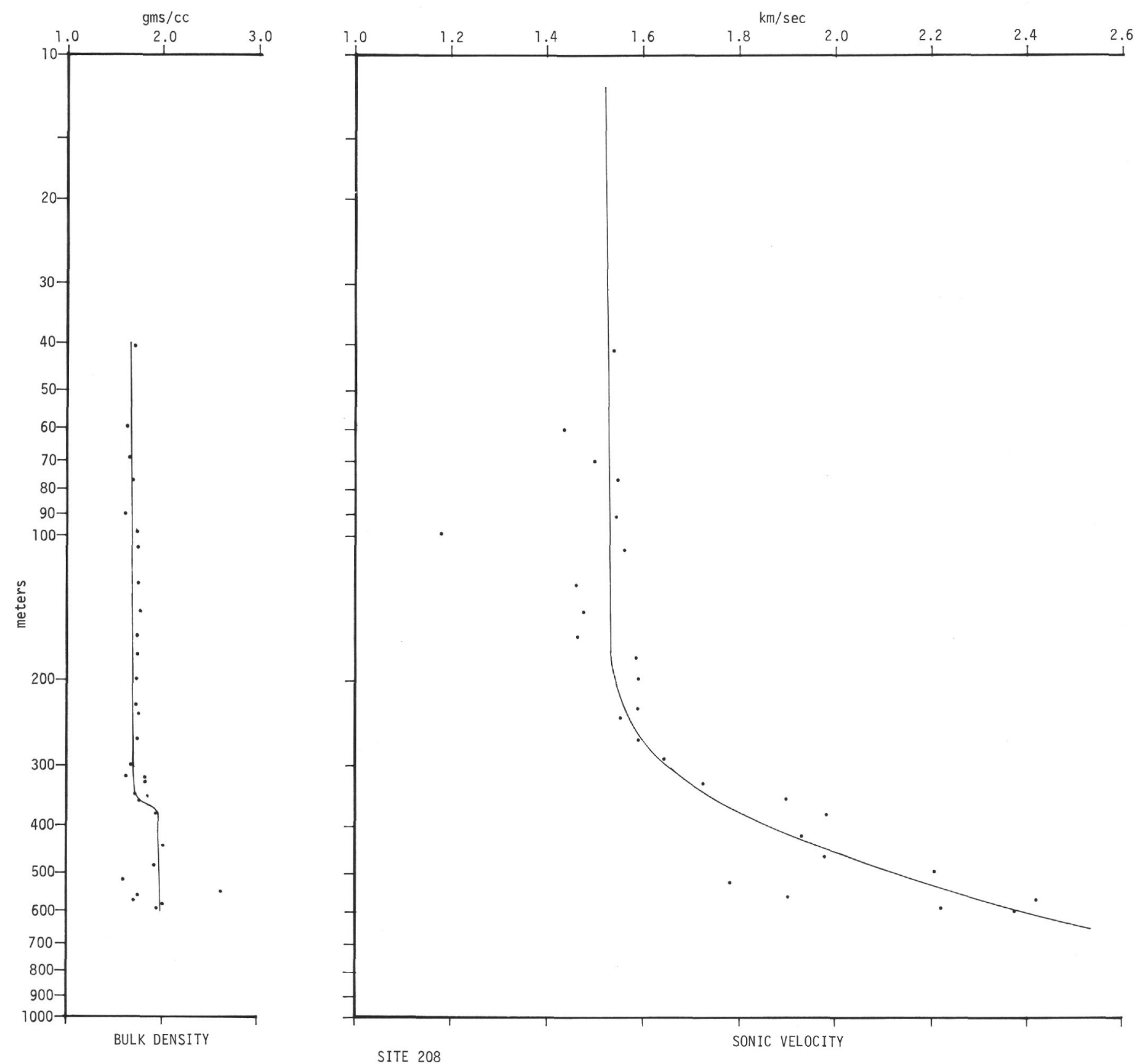

Figure 5. Plot of bulk density and sonic velocity against depth for Site 208.

\section{MICROSCOPIC FEATURES OF THE SEDIMENTS}

Samples from each of the sites were examined by means of an SEM. The samples comprise 15 from Site 206, 6 from Site 207, 16 from Site 208, and 10 from Site 210. One sample from Site 207 and four samples from Site 208 were examined as disaggregated sediment, the remainder were semilithified sediments of which broken surfaces were examined. The depths (subbottom) from which the samples came are indicated on Figure 2.

The identification of the material seen in the SEM photographs has been made possible by the assistance of Mr. A. R. Edwards, who has pointed out to us features of the preservation of the nannoplankton, and with the aid of such well illustrated works as Berger and von Rad (1972). One of the unresolved issues is the nature of the siliceous diagenetic products. In the $\mathrm{X}$-ray determinations both cristobalite and tridymite have been found. The cristobalite is generally referred to by workers on cherts as low-cristobalite (see Berger and von Rad, for example). All that we can do is point out that in the samples we studied, we have found occurrences similar to the ones that they recorded, and have illustrated most of them.

\section{Site 206}

The samples examined from this site are shown in Table 1. 

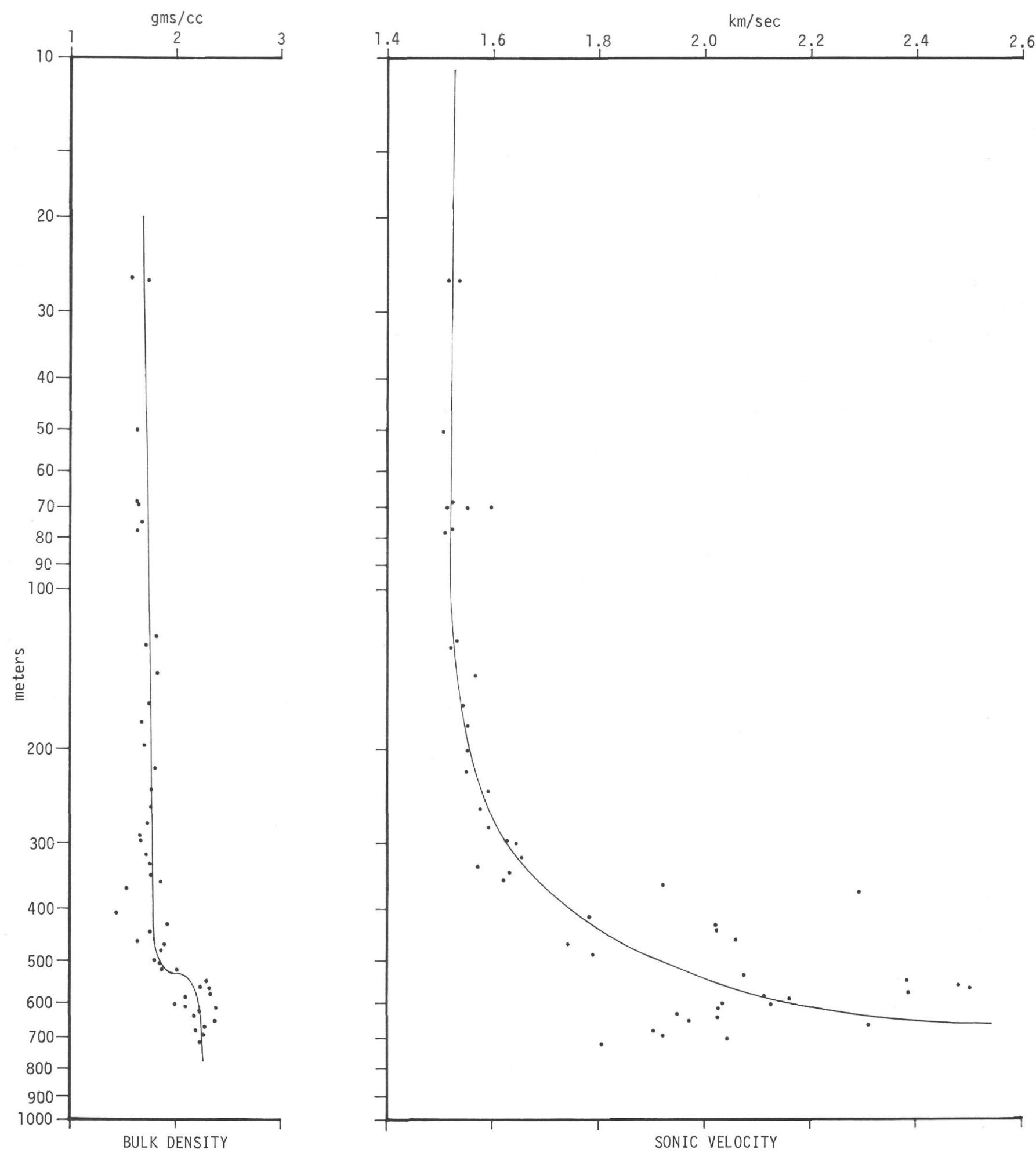

SITE 210

Figure 6. Plot of bulk density and sonic velocity against depth for Site 210.

The samples examined from this site include only the sediments that are sufficiently coherent to examine broken surfaces. In the shallowest sample studied (from $315.1 \mathrm{~m}$ ), the larger coccoliths show solution of their edges and the deposition of some secondary calcite in their central regions. The former feature is probably an original feature of the grains, while the latter is a post-depositional phenomenon. The sediment has an open porous texture (Plate 1, Figure 1). It is composed of coccoliths, coccolith fragments, and smooth flaky bodies (presumably phyllosilicates). There is a minor development of the sheetlike structures bridging between grains that are very strongly 
TABLE 1

Samples Examined from Site 206

\begin{tabular}{|c|c|c|}
\hline $\begin{array}{l}\text { Subbottom } \\
\text { Depth }(\mathrm{m})\end{array}$ & Age & Lithology \\
\hline 315.1 & Early Miocene & Foram- and clay-bearing nanno ooze. \\
\hline 399.4 & Early Miocene & Foram-bearing clay nanno ooze \\
\hline 447.1 & Late Oligocene & Foram-bearing clay-rich nanno ooze \\
\hline 499.6 & Late Oligocene & $\begin{array}{l}\text { Sponge spicule and foram-bearing } \\
\text { clay-rich nanno ooze }\end{array}$ \\
\hline 533.9 & $\begin{array}{l}\text { Middle } \\
\text { Oligocene }\end{array}$ & $\begin{array}{l}\text { Sponge spicule-bearing clay-rich } \\
\text { nanno ooze }\end{array}$ \\
\hline 554.2 & $\begin{array}{l}\text { Middle } \\
\text { Oligocene }\end{array}$ & $\begin{array}{l}\text { Sponge spicule- and clay-bearing } \\
\text { nanno ooze }\end{array}$ \\
\hline 567.8 & $\begin{array}{l}\text { Middle } \\
\text { Oligocene }\end{array}$ & Clay-rich nanno ooze \\
\hline 588.1 & $\begin{array}{l}\text { Middle } \\
\text { Oligocene }\end{array}$ & Foram-bearing, clay-rich nanno ooze \\
\hline 605.6 & $\begin{array}{l}\text { Middle } \\
\text { Oligocene }\end{array}$ & Clay-rich nanno ooze \\
\hline 614.1 & Late Eocene & $\begin{array}{l}\text { Sponge spicule-, diatom-, and foram- } \\
\text { bearing calcic-rich nanno rad ooze }\end{array}$ \\
\hline 635.2 & Middle Eocene & $\begin{array}{l}\text { Foram- and sponge spicule-bearing } \\
\text { rad-rich calcic nanno ooze }\end{array}$ \\
\hline 652.7 & Middle Eocene & $\begin{array}{l}\text { Diatom-, foram-, and sponge spicule- } \\
\text { bearing, rad-rich calcic nanno ooze }\end{array}$ \\
\hline 670.7 & Middle Eocene & $\begin{array}{l}\text { Sponge spicule-, diatom-bearing, rad, } \\
\text { and nanno-rich calcic ooze }\end{array}$ \\
\hline 688.3 & Early Eocene & $\begin{array}{l}\text { Foram-, and nanno-bearing calcic } \\
\text { ooze }\end{array}$ \\
\hline 707.3 & Early Paleocene & Nanno-rich calcic clay \\
\hline
\end{tabular}

developed in sediments from Site 208. The second sample, from 399.4 meters, is very similar to the previous one (Plate 1, Figure 2), except that the amount of coccolith solution is much less and the abundance of bridging structures is greater. An uncompressed coccosphere was located in this sample (Plate 1, Figure 3) indicating that the degree of compaction is small. At 477 meters there is a similar array of characteristics. The more clayey nature of the sediment is evident in the frequency of flaky grains. In patches of fine carbonate, there is an appearance of welding of the grains and softening of their outlines. These same features are observed in the sample from 499.6 meters (Plate 1, Figures 4 and 5). The commencement of welding of the grains occurs where the sediment becomes semilithified.

A distinct change in the degree of diagenesis occurs between the previous sample and the one from 533.9 meters. In the latter, there is a considerable degree of welding of the finer grains and a softening of their outlines, together with the development of conspicious overgrowths on the larger coccoliths. This is the level at which there is a rapid increase in bulk density. The next sample (from 554.2 $\mathrm{m})$ according to the X-ray data, contains about $9 \%$ phyllosilicates in the crystalline material compared with about $3 \%$ for the previous sample. The sediment contains abundant wisps and cellular masses of these minerals among the carbonate grains, which again show softened outlines. The larger coccoliths are distinctly pitted and corroded around the margins, and some overgrowths occur (Plate 1, Figure 6).

The degree of welding and smoothing of the fine grains in the sample from 567.8 meters (Plate 2, Figure 1) is much greater than that seen in the sample from 533.9 meters. This is the level at which small faults and slickensides make their appearance. The larger coccoliths are corroded around the margins and pitted. The sample from 588.1 meters (Plate 2, Figure 2) is very similar, as is the sample from 605.6 meters (Plate 2, Figure 3), but it also contains clinoptilolite and more abundant granular calcite overgrowths on the coccoliths.

Beneath the mid-Tertiary unconformity, the sediments are more siliceous at this site. The sample from 614.1 meters contains only $56 \%$ calcium carbonate. The nature of the diagenetic carbonate is again similar to the previous samples but instead of the fine carbonate forming a groundmass between the larger coccoliths, it occurs as patches encrusting both siliceous and calcareous remains (Plate 2, Figure 4). The sample from 632.2 meters is once again more calcareous ( $83 \%$ calcium carbonate). It shows a patchy development of fine carbonate, frequent development of sheetlike bridges between grains, occasional large diagenetic crystals of calcite and clinoptilolite, and variable degrees of solution and breakage of coccoliths.

The fine carbonate in the sample from 652.7 meters is much more crystalline than in any of the higher samples (Plate 2, Figure 5). This sample contains only $64 \%$ calcium carbonate. The porosity of the sediment appears to be much less. The large coccoliths are corroded and overgrown. The sample from 670.7 meters is very similar (Plate 2, Figure 6 and Plate 3, Figure 1).

In a highly calcareous sample from 688.3 meters the same degree of recrystallization can be seen. The different responses of various biogenic materials can be seen. The wall structures of forams are completely destroyed by overgrowths of coarse calcite crystals (Plate 3, Figure 2). Coccoliths are partly dissolved, while discoasters appear to be untouched. Layers of finely crystalline carbonate occur through the sample; associated with this are small spherules of cristobalite (Plate 3, Figure 3). These pass into wispy sheets resembling the sheetlike bodies noted earlier.

The deepest sample examined is from 707.3 meters. It is composed of corroded and strongly overgrown coccoliths, fine crystalline calcite, and flaky phyllosilicates (Plate 3, Figure 4).

\section{Site 207}

The samples examined are shown in Table 2.

TABLE 2

Samples Examined from Site 207

\begin{tabular}{cll}
\hline $\begin{array}{c}\text { Subbottom } \\
\text { Depth }(\mathrm{m})\end{array}$ & \multicolumn{1}{c}{ Age } & \multicolumn{1}{c}{ Lithology } \\
\hline 171.3 & mid Middle & $\begin{array}{l}\text { Sponge spicule-, radiolarian, and } \\
\text { foram-bearing nanno ooze }\end{array}$ \\
& Eocene & Foram-rich nanno ooze \\
278.1 & Early Eocene & Foram-rich nanno chalk \\
293.7 & Middle Paleocene & Silty claystone \\
310.1 & Maastrichtian & Silty claystone \\
319.3 & Maastrichtian & Malidian \\
\hline
\end{tabular}

The sample from 171.3 meters is not sufficiently consolidated to be examined in a fractured surface. The nannoplankton remains in this sample show no clear sign of post-depositional solution.

At 278.1 meters, the sediment is semilithified. This sample that comes from the vicinity of a chert layer 
contains occasional radiating cristobalite bodies about $3 \mu$ in diameter (Plate 3, Figure 5). Well-formed crystals of clinoptilolite to about $10 \mu$ in length are common. The coccoliths are well preserved but show some slight degree of dissolution. They are encrusted by scattered equant crystals presumably of calcite about 0.5 to $1 \mu$ in diameter (Plate 3, Figure 6). In places, patches of the sediment appear to be cemented by aggregates of these crystals.

There is a considerable increase in the abundance of the small calcite crystals in the next sample from 293.7 meters (Plate 4, Figure 1). Clinoptilolite crystals are again common. This is the lowest of the carbonate sediments examined. The next lithology (silty claystone) commences at 309 meters.

The silty claystone unit represented by samples from 310.1 meters and 319 meters is lithologically very uniform. The average composition of the crystalline phases from $\mathrm{X}$-ray analysis is as follows: quartz, $7 \%$; cristobalite, $69 \%$; potash feldspar, $2 \%$; plagioclase, $3 \%$; mica, $1 \%$; montmorillonite $3 \%$; tridymite, $12 \%$; clinoptilolite, $1 \%$; and pyrite, $2 \%$. The most obvious feature of the SEM photographs of this rock is the abundant spheres of cristobalite (Plate 4, Figure 2). They are about 2 to $3 \mu$ in diameter. Flaky material amongst the spheres is probably mica and montmorillonite (Plate 4, Figure 3). Occasional well-formed crystals are encountered which are probably clinoptilolite and perhaps potash feldspar. In spite of the massive development of diagenetic minerals in this sediment, there is still substantial pore space, possibly about $30 \%$.

Apart from the sample from 171 meters, all the others are semilithified and below the level at which the bulk density increases rapidly.

\section{Site 208}

The samples examined from this site are shown in Table 3.

TABLE 3

Samples Examined from Site 208

\begin{tabular}{rll}
\hline $\begin{array}{c}\text { Subbottom } \\
\text { Depth }(\mathrm{m})\end{array}$ & \multicolumn{1}{c}{ Age } & \multicolumn{1}{c}{ Lithology } \\
\hline 0.1 & Late Pleistocene & Foram-rich nanno ooze \\
68.4 & Early Pliocene & Foram nanno ooze \\
160.4 & Late Miocene & Foram-rich nanno ooze \\
288.8 & Middle Miocene & Foram-rich nanno ooze \\
319.6 & Early Miocene & Foram-rich nanno chalk \\
347.0 & Early Miocene & Foram nanno chalk \\
402.5 & Early Miocene & Foram-rich nanno chalk \\
431.3 & Late Oligocene & Foram-rich nanno chalk \\
460.4 & Late Oligocene & Foram-bearing nanno chalk \\
487.9 & Middle Eocene & Sponge spicile and rad-rich nanno \\
& & chalk \\
514.8 & Middle Eocene & Glauconite and diatom-bearing \\
& & sponge spicule nanno chalk \\
542.5 & Middle Paleocene & Nanno chalk \\
551.9 & Early Paleocene & Rad and sponge spicule nanno \\
& & chalk \\
559.3 & Early Paleocene & Calcic-bearing rad diatom and \\
& & sponge spicule-rich nanno chalk \\
579.9 & Late Maastrichtian & Nanno-bearing calcic chalk \\
589.4 & Late Maastrichtian & Nanno-rich calcic chalk \\
\hline
\end{tabular}

The first four samples are not sufficently consolidated to obtain broken surfaces for examination. The two lower samples contain broken coccolith fragments which are strewn over the more complete tests. It is not obvious whether this is a feature of the original sediment or a phenomenon associated with the first stages of lithification. In view of the excellence of preservation of the coccoliths at greater depths here and elsewhere, it is more likely be a feature of the original clastic material.

The samples from 319, 347, and 402 meters all have a very porous open texture. They are composed predominantly of whole coccoliths and small plates which appear to be individual plates of coccoliths. In these samples the abundance of the plates increases markedly downwards, from a few percent in the highest sample to perhaps $20 \%$ in the lowest one where there is the first suggestion of the welding together of these grains. This is just below the level at which the sediments were described as semilithified.

The sample from 431 meters shows more distinct evidence of diagenesis. This sediment contains $78 \%$ calcium carbonate. The coccoliths have indications of solution (irregular outlines and pits); smaller grains appear to be partly welded to the larger ones (Plate 4, Figure 4); some grains appear to be connected by irregular sheets of silica (?) or clay (?); and there are areas which appear to be coated with an "icing" of mineral matter (Plate 4, Figure 5). If the solution of the calcite is post-depositional, then the process involved appears to be solution at some points (presumably points of contact of grains under pressure) and deposition at others.

The next sample is from just under 30 meters deeper, at 460.4 meters. Solution of the coccoliths is more advanced than in the previous sample. There is more pitting and the outlines are more irregular. Patches of very finely crystalline material are present (Plate 4, Figure 6); foram tests contain crystalline linings and ? clinoptilolite needles (Plate 5 , Figure 1). The sheetlike features of the previous sample are less common. This sample has a similar carbonate percentage to the previous one $(84 \%)$.

Beneath the Oligocene-Eocene unconfirmity there is a marked change in the composition of the biogenic components. Radiolaria and sponge spicules are present in quantity in the nanno ooze, and the calcium carbonate percentage in the next sample $(478.9 \mathrm{~m})$ examined is $57 \%$. The coccoliths show a degree of solution similar to the previous sample, but in addition there is a stronger development of overgrowths on the coccoliths, and the sheetlike structures seen higher are again common. The sediment is still very porous. The next sample from 514.8 meters is very similar (Plate 5, Figure 2).

With the increase in calcium carbonate content to $81 \%$ in the sample from 542.5 meters, there is another marked change in the appearance of the sediment. A further development of the features observed in the samples from 431 and 460 meters is seen. The most distinctive is the degree of welding together of the grains apparently brought about by solution and redeposition of calcite (Plate 5, Figure 3). The coccoliths show distinct solution and overgrowth; there is a frequent development of sheetlike structures joining grains. Small grains, about $0.5 \mu$ in diameter, are scattered through the sediment; they appear to be coccolith platelets. The degree of solution that has taken place results in some areas in the sediment becoming 
very smoothed, and the individual grains are no longer recognizable as such, nor is their original nature determinable. The two following samples from 551.9 and 559.3 meters are more siliceous, containing $77 \%$ and $66 \%$ calcium carbonate, respectively. They show more evidence of solution than the previous sample, and appear to be more porous. The sorting also appears to be not as good. There seems to be a larger proportion of grains less than $1 \mu$ in diameter. The degree of smoothing of grains is much less and sheetlike structures are less common (Plate 5, Figure 4).

The last two samples studied (from 579.9 and 589.4 meters) both contain cristobalite, clinoptilolite, and minor amounts of barite (Plate 6, Figure 2). Both samples display varied features. The coccoliths vary from very strongly affected by solution to extremely well preserved. Some areas show smoothing of grains (Plate 5, Figure 5); others have large well-formed carbonate crystals (up to $2.5 \mu$ in diameter, Plate 6, Figure 1). Spherules of cristobalite are 2 to $3 \mu$ in diameter (Plate 5, Figure 6). They grow on and between coccoliths which range from extremely well preserved to very strongly affected by solution.

\section{Site 210}

At Site 210 calcareous sediments occur sporadically in the upper part of the sequence in the turbidites, but they are more common in the lower part where they contain various degrees of terrigenous intermixtures. The samples studied from this site are shown in Table 4.

TABLE 4

Samples Examined from Site 210

\begin{tabular}{|c|c|c|}
\hline $\begin{array}{l}\text { Subbottom } \\
\text { Depth }(\mathrm{m})\end{array}$ & Age & Lithology \\
\hline 441.5 & Late Miocene & Nanno ooze \\
\hline 480.0 & $\begin{array}{l}\text { Late Middle } \\
\text { Miocene }\end{array}$ & Silty clay \\
\hline 523.6 & Middle Oligocene & Clay-rich nanno ooze \\
\hline 546.5 & Late Eocene & Clay-bearing calcic nanno chalk \\
\hline 551.8 & Middle Eocene & Clay-rich calcic nanno chalk \\
\hline 569.0 & Middle Eocene & $\begin{array}{l}\text { Foram-bearing nanno-rich } \\
\text { calcareous clay }\end{array}$ \\
\hline 590.5 & Middle Eocene & Calcic-rich clay nanno chalk \\
\hline 653.2 & Early Eocene & $\begin{array}{l}\text { Foram and calcic-bearing nanno } \\
\text { clay }\end{array}$ \\
\hline 707.8 & Early Eocene & $\begin{array}{l}\text { Foram-bearing calcic-rich nanno } \\
\text { clay }\end{array}$ \\
\hline
\end{tabular}

Parts of the shallowest sample examined from this hole have been considerably modified by diagenesis (Plate 6, Figure 3). The most obvious effects are seen in the groundmass between the coccoliths. The finer grains are firmly welded together and their original features completely obscured, although other parts of the same sample are porous (Plate 6, Figure 4). The coccoliths are both corroded and overgrown. This sample comes from a bed which is interbedded with clays and fine-grained turbidites. Its chemical environment is likely to be different from that in sequences composed entirely of ooze.

The next two samples come from an abyssal clay unit. The higher one is noncalcareous (Plate 6, Figure 5), and the lower one contains minor carbonate. Both samples are composed predominantly of flaky grains of phyllosilicates, the lower one containing smooth areas which are presumably carbonate.

Below the abyssal clay is a unit of nanno ooze; this resembles the nanno ooze above the abyssal clay except that the degree of welding of grains is more uniform. The sediment is porous (Plate 6, Figure 6). The clay appears as small patches of flaky material.

The rapid increase in bulk density occurs just above the regional unconformity. The next sample examined is from below both of these features $(546 \mathrm{~m})$. It is much more compact, has a much greater degree of welding of grains than the previous sample (Plate 7, Figure 1), and granular calcite crystals appear.

The samples from 546 to 708 meters show a progressive amount of recrystallization with increasing depth (Plate 7 , Figures 1 to 6$)$. In the deepest sample the groundmass in strongly recrystallized, and the coccoliths are strongly overgrown and show the effects of partial solution (Plate 7, Figure 6). Some other points of interest emerge from the study of these samples. There is an increasing clay content in these sediments down the succession. The carbonate content decreases from about $85 \%$ at the top to about $30 \%$ at the bottom. In the lower part of the sequence slickensided surfaces are common. These are coated with clay, and adjacent to them the carbonate has been dissolved leaving randomly oriented flakes of phyllosilicates (Plate 7, Figure 5 ). In this way, presumably redistribution of the carbonate takes place, being dissolved near the movement plane and redeposited in adjacent parts of the sediment. In the sample from 590.5 meters cristobalite has developed, but because of the significant terrigenous component of the sediment, the development of discrete spherules of the mineral has been inhibited, and their development is irregular.

\section{DISCUSSION AND CONCLUSIONS}

\section{General Diagenetic Sequences}

The principal results from the examination of the physical properties and macroscopic appearance of the sediments are plotted in Figure 2. The sediments with a creamy texture show deformation of 3 to 4 except in the more clayey sequence of Site 210, where in the lower part of the creamy zone they have deformation of 2 to 3 . The more consolidated stiff sediments display a deformation of 2 to 3 except in the basal 10 to 20 meters at Sites 207, 208, and 210 . In the lower part of the zone of stiff sediments there is a change from plastic sediments to slightly crumbly sediment. This change corresponds approximately to the level at which there is a change in the gradient of the depth-sonic velocity curve. Possibly this is the point at which the pore water is squeezed out to such an extent that a grain framework is established. Only three samples were examined from the stiff zone; it is possible that the compaction which occurs in the lower part of that zone is the result of (a) grain breakage, as Schlanger et al. (in press) suggest, (b) solution at grain contacts, and (c) development of overgrowths.

The upper boundary of the semilithified zone is the level at which welding of grains first appears. Welding is presumably the result of grain solution at contacts. The 
welding of grains becomes more prominent downwards. We have not been able to evaluate the role of grain breakage in the process of compaction in the semilithified zone, except that in the upper part of the zone at Site 208, there is a marked downward increase in the proportion of fine coccolith fragments.

The discontinuity in the bulk density-depth curve occurs well within the semilithified zone. This is about the depth at which granular calcite overgrowths and void fillings appear. This phenomenon is more prominent at the sites at which the inflection of the bulk density curve occurs at greater depth. The rapid increase of bulk density, one might argue (with little evidence), takes place when the process of breakage of grains with some solution at their contacts (Plate 2, Figure 5) is replaced by one involving much more rapid solution and recrystallization. There is, naturally, a marked reduction in visible pore space at this level. The change in mechanical response to consolidation which takes place at or below this level, which is indicated by the appearance of minor faults, is presumably the result of compressional strain no longer being taken up by intergranular reorganization because of the increased strength of the sediment.

A general correlation between the results obtained here and those of Schlanger et al. can be seen; it will be possible to pursue the comparison further when a full account of their findings is available.

\section{Comparison of Sites}

Because of the regular organization of the various phenomena in the various sequences discussed, it is apparent that as deposition takes place the various surfaces defined move up the column as sediment accumulates. Since all the successions under discussion, except for that at Site 210 , are highly calcareous, it is reasonable to expect that the depths at which the changes take place should be comparable from one site to another. From Figure 2 it is clear that this is not the case, i.e., the lithification pattern is not a simple function of depth of burial. One factor which might contribute to differences is the thermal gradients. Measurements made in the drill holes at Sites 206 and 210 gave thermal gradients of $0.050^{\circ} \mathrm{C} / \mathrm{m}$ and $0.097^{\circ} \mathrm{C} / \mathrm{m}$, respectively, and yet the levels at which the various changes take place in each hole are closely similar. It was pointed out earlier that the lithification pattern was unrelated to the regional unconformity and is not a simple function of time. Further, the lithification transitions are shallowest at the site where the sedimentation rate has been the lowest, namely, Site 207; next shallowest at Site 208, where the sedimentation rate has been higher; and deepest at Sites 206 and 210, where the sedimentation rates have been highest. The microscopic features seen at each site are broadly comparable in style, but in the sites with the lower sedimentation rates, the increase in bulk density and consequent reduction in porosity is less. These considerations suggest that the degree of lithification of oceanic sediments is dependent in some way on both depth of burial and time. A review of the vast amount of data collected by the Deep Sea Drilling Project might elucidate the nature of this relationship.

\section{Lithification Boundaries and Seismic Reflectors}

In the course of the investigation of the drill sites under discussion, it was not possible to relate all of the seismic reflectors to the lithology changes. In Figure 1, the depths of the various reflectors recognized onboard the ship and the depths calculated onboard have been plotted. Also plotted are the stratigraphic columns and the lithification phenomena which are likely to be of some significance in causing reflection events to occur. The most significant are the points at which there are rapid increases in sonic velocity and the depth at which there are rapid increases in bulk density. Of possible lesser significance are the degrees of deformation of the cores and the degree of lithification. Stepwise changes in these parameters should also be reflected in the velocity and/or density data but the magnitude of the effects may be too small to be detected by the methods employed.

At Site 206, there is no obvious reason for reflectors to occur on account of lithological changes; however, they appear to bear a clear relationship to lithification changes. $\mathrm{R} 1$, a faint reflector, might be attributed to either the change in deformability or the change from creamy to stiff in texture. $\mathrm{R} 2$ could be attributed to the increase in sonic velocity. R3 occurs at another discontinuity in the deformability and at the boundary of stiff and semilithified sediment. R4 occurs in the region of the rapid increase in bulk density. There is no obvious diagenetic reason for Reflectors 5 and 6.

The correlation between reflectors and lithification features at Site 210 is not as good as that at Site 206. R1, a moderately strong reflector, is about 25 meters above the level of the rapid increase of sonic velocity, and there is no reflector at the boundary between stiff and creamy sediment. R2, however, lies close to the boundary between stiff and semilithified sediments. At R3, there is both a bulk density change and a marked lithological change from abyssal clay to nanno chalk. The explanation of R4 is not apparent.

The situation at Site 207 is complicated by the relative shallowness of the mid-Tertiary unconformity and the presence of chert horizons in the Paleogene section. R1 could be interpreted as due to the unconformity, or possibly the junction between stiff and creamy sediments. R2 occurs near the upper boundary of the semilithified sediments, and the rapid increase in sonic velocity. Alternatively, it might be the result of the presence of chert bands. The increase in bulk density at this site is small, and so a reflector at that level is not likely. Reflectors 3 and 4 come from a level below the bulk density increase. The former might be related to chert horizons. The fourth reflector occurs at the top of the silty clay unit.

At Site 208, the section is thicker and more uniform than that at Site 207. The first reflector, which is faint, occurs once again at the level where there is a drop in the degree of deformation of the cores, and above the upper boundary of stiff sediments. The second reflector occurs at the horizon at which there is a rapid increase in sonic velocity. There is no reflector at the upper boundary of the semilithified zone although this might have been masked by R2. At this site, the highest semilithified sediments are much less compact than at Sites 206 and 210. Although an 
increase in bulk density at the inflection (about $370 \mathrm{~m}$ ) is smaller than at the other sites, a moderate to strong reflector (R3) occurs at that level. R4 may be the result of an increase in the degree of diagenesis; it is at about that depth that the amount of welding of grains increases substantially. The fifth reflector may be associated with the unconformity, and the sixth could be related to chert horizons.

In conclusion, it appears that in the essentially biogenic carbonate sequences studied here, the ideal sequence of seismic reflectors might be explained as follows:

$\mathrm{R} 1$-The first reflector is weak and occurs at about the level where the deformation of the sediments drops from 3 to 4 , to 2 to 3 , or where the sediments pass from creamy to stiff.

$\mathrm{R} 2-$ This reflector is at about the level where the stiff sediment becomes crumbly. This is about the depth at which the sonic velocity starts to increase more rapidly with depth.

R3-The third reflector approximates the boundary of stiff and semilithified sediments. In the sites where the sedimentation rates are greatest, this reflector is best developed. When the semilithification boundary is shallower, the degree of welding of the grains is less and this reflector could be absent.

R4-This occurs at the level at which the bulk density increases more rapidly. It is the point at which granular calcite overgrowths appear in quantity and the pore space is considerably reduced.

No further pattern of deeper reflectors associated with further diagenetic changes has been recognized.

\section{ACKNOWLEDGMENTS}

Scanning electron photomicrographs of samples from Sites 206 and 210 were taken on the SEM of Sydney University, Australia. We are grateful to Dr. Clive Nockolds for his assistance. The photomicrographs of samples from Sites 207 and 208 were taken on the SEM of the Physics and Engineering Laboratory, Department of Scientific and Industrial Research, Lower Hutt, New Zealand. We are grateful to Mr. D. M. Hall, Mr. W.S. Bertaud, and Mrs. Lesley A. Donaldson for their support and assistance. We would also like to thnk Mrs. Diana Packham for typing the manuscript and drafting the figures.

\section{REFERENCES}

Berger, W. H. and von Rad, U., 1972. Cretaceous and Cenozoic sediments from the Atlantic Ocean: In Hayes, P. E., Pimm, A. C., et al. Initial Reports of the Deep Sea Drilling Project, Volume XIV: Washington (U.S. Government Printing Office), p. 787.

Davies, T. A. and Supko, P. R., 1973. Oceanic sediments and their diagenesis: some examples from deep sea drilling: J. Sediment. Petrol., v. 3, 381-390.

Laughton, A. S., 1954. Laboratory measurements of seismic velocities in ocean sediments: Roy. Soc. London Proc., v. A222, p. 336-341.

Schlanger, S. O., Douglas, R. G., and Roth P. R., and Moore, T. C., Jr., in press. Progressive diagenesis of carbonate deep-sea sediments at Deep Sea Drilling Site 167, Magellan Rise: In Winterer, E. L., Ewing, J. I., etal. Initial Reports of the Deep Sea Drilling Project, Volume XVII. Washington (U.S. Government Printing Office). 
PLATE 1

SEM photographs, Site 206

Figure 1315.1 meters (Early Miocene). Nanno ooze from the stiff zone. Coccoliths show some solution and minor overgrowths. $\times 2000$.

Figure 2399.4 meters (Early Miocene). Ooze similar to Figure 1 from the bottom of the stiff zone. $\times 2000$.

Figure 3 Detail of Figure 2. Coccosphere. $\times 6000$.

Figure $4 \quad 499.6$ meters (Late Oligocene). Nanno ooze from the semilithified zone showing welding and softening of the outlines of grains. Radiolarian test on left. $\times 1000$

Figure 5499.6 meters (Late Oligocene). Nanno ooze with more open texture, flaky clay minerals and welded fine grains. $\times 2000$.

Figure $6 \quad 554.2$ meters (Middle Oligocene). Nanno ooze with areas of phyllosilicates. Coccoliths are pitted and corroded. $\times 6000$. 
PLATE 1
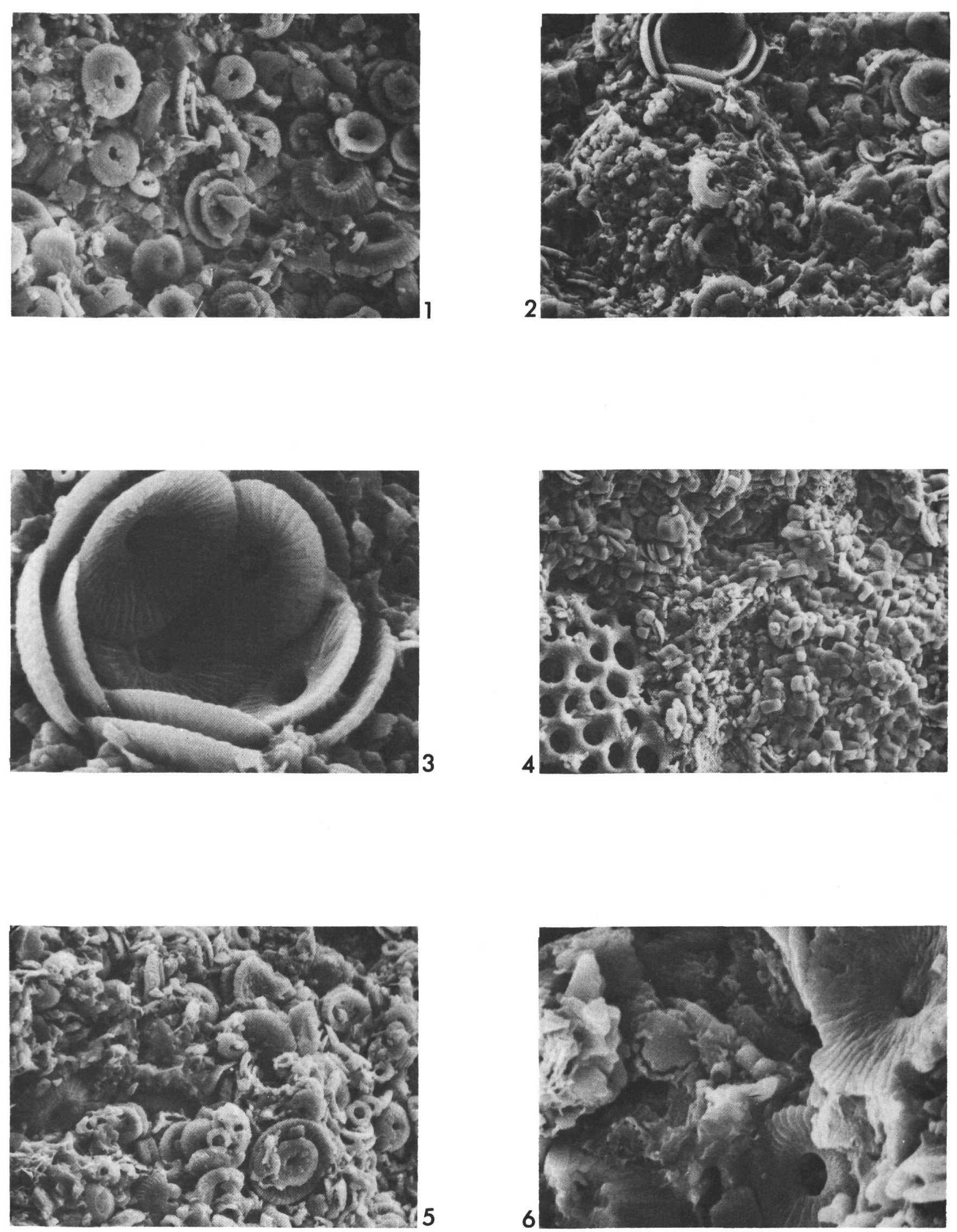
PLATE 2

SEM photographs, Site 206

Figure 15567.8 meters (Middle Oligocene). Much more compact and crystalline nanno ooze from semilithified zone. The calcite matrix has a granular appearance. $\times 2000$.

Figure 2588.1 meters (Middle Oligocene). Nanno ooze similar to Figure 1. A foram chamber is lined with calcite crystals. $\times 2000$.

Figure 3 605.6 meters (Middle Oligocene). Nanno ooze with coccoliths showing considerable modification. $\times 2000$.

Figure 4614.1 meters (Late Eocene). Nanno rad ooze with granular calcite overgrowths on coccoliths. $\times 2000$.

Figure $5 \quad 652.7$ meters (Middle Eocene). Nanno calcic ooze with crystalline matrix. Coccolith showing solution and overgrowths. $\times 6000$.

Figure 6

670.7 meters (Middle Eocene). Calcic ooze with coccoliths almost obscured by granular calcite. $\times 2000$. 
PLATE 2
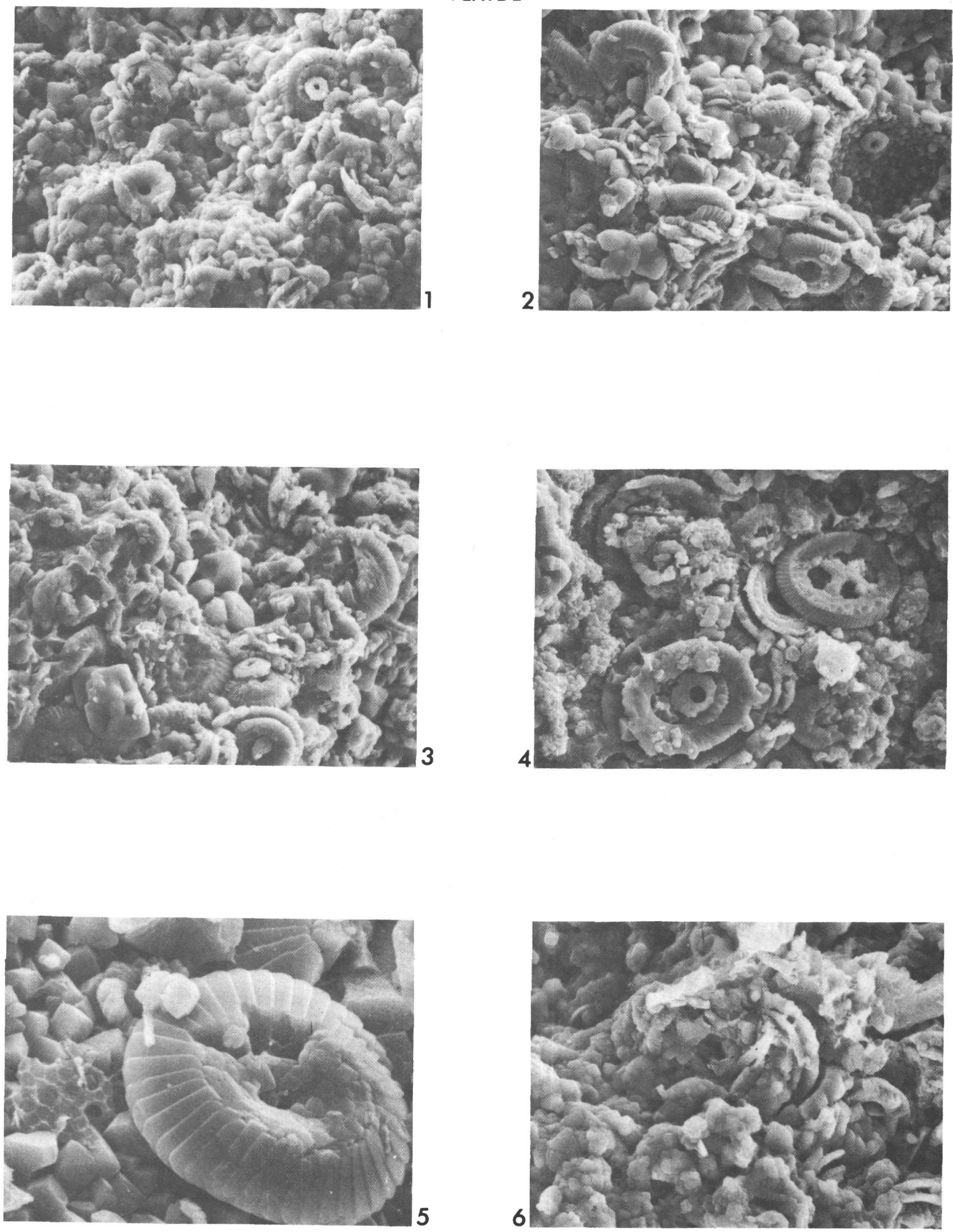
PLATE 3

SEM photographs, Site 206

Figure 1

Figure 2

Figure 3

Figure 4

Figure 5

Figure 6
670.7 meters (Middle Eocene). Calcic ooze with calcite crystals growing on a siliceous fragment. $\times 2000$.

688.3 meters (Early Eocene). Foram with wall structure destroyed by development of large calcite crystals. Clinoptilolite crystals inside relict chamber. $\times 1000$.

688.3 meters (Early Eocene). Matrix of calcite crystals in calcic ooze, crudely spherical masses of cristobalite (right), and a coccolith still showing good preservation. $\times 6000$.

707 meters (Early Paleocene). Calcic clay showing highly modified coccoliths, crystalline calcite matrix, and flaky phyllosilicates. $\times 2000$.

SEM photographs, Site 207

278.1 meters (Early Eocene). Cristobalite sperules, clinoptilalite crystals, and granular calcite crystals from nanno ooze. $\times 5800$.

278.1 meters (Early Eocene). Nanno chalk from semilithified zone, coccoliths, etc., encrusted with granular calcite crystals. $\times 2300$. 


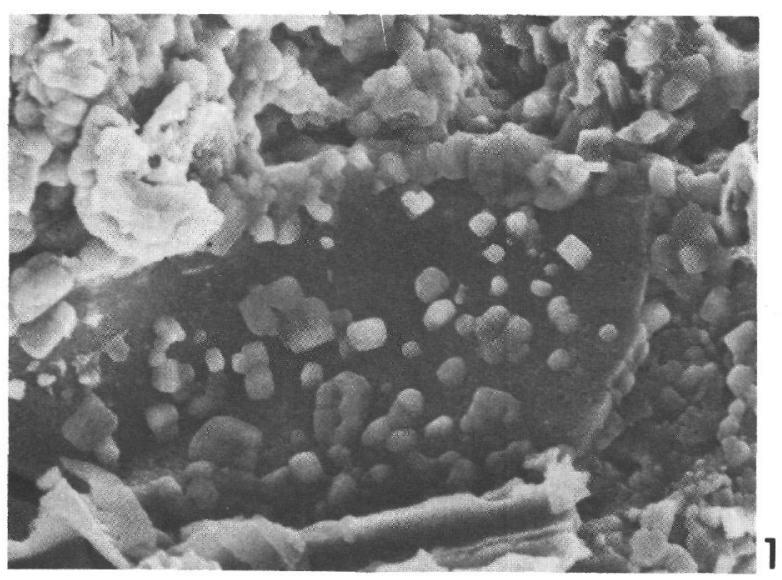

\section{PLATE 3}
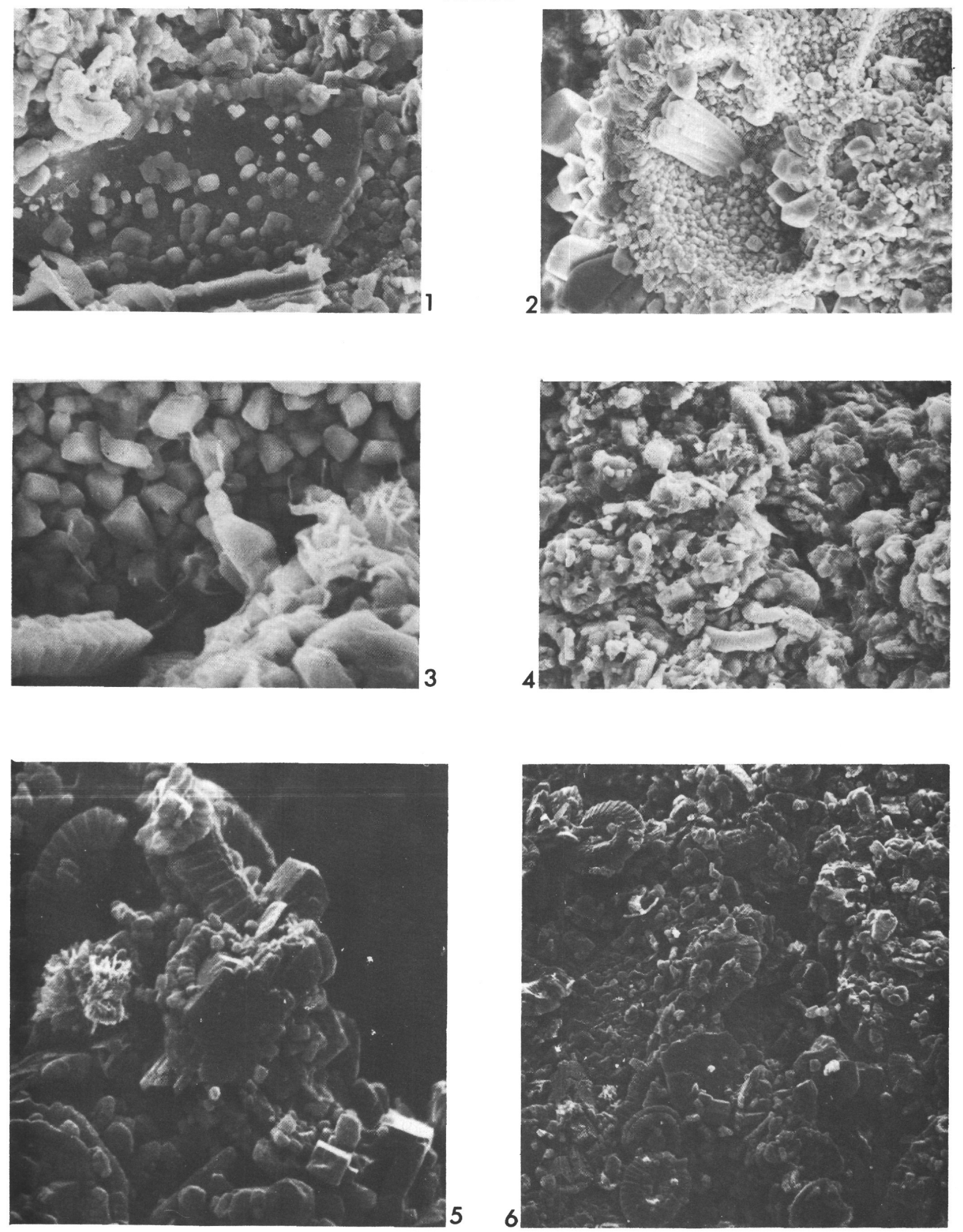

5

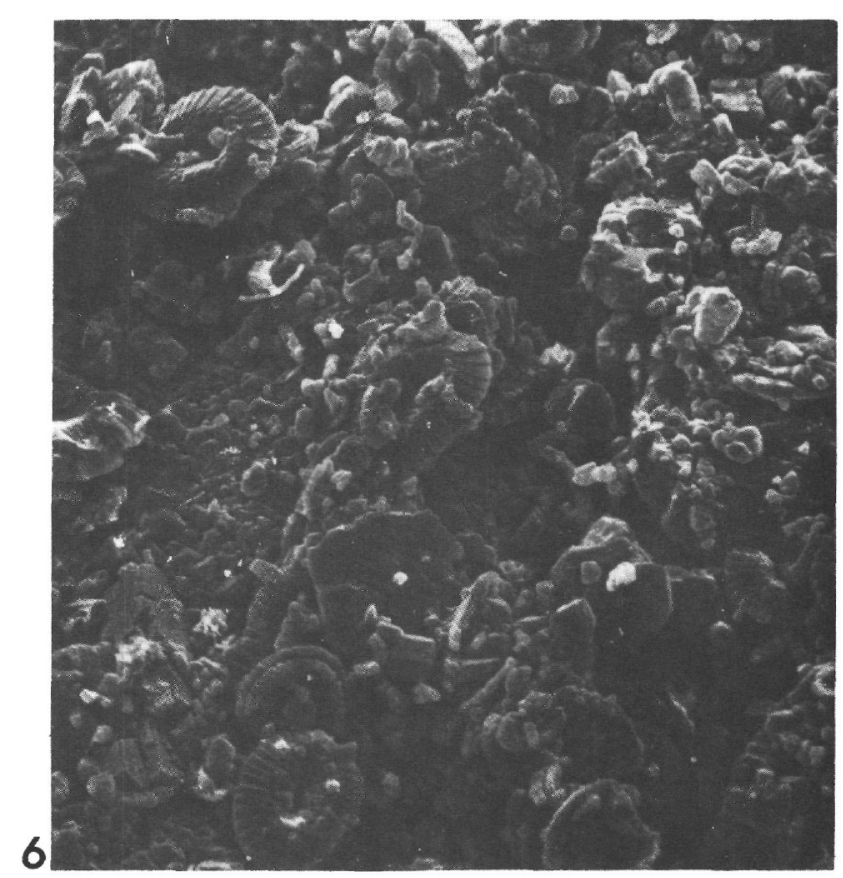




\section{PLATE 4}

SEM photographs, Site 207

Figure 1293.7 meters (Middle Paleocene). Nanno chalk with granular calcite crystals encrusting coccoliths. $X 2700$.

Figure $2 \quad 319.3$ meters (Maastrichtian). Cristobalite spherules with well-formed unidentified authigenic crystals (? clinoptilolite) from silty claystone. $\times 6300$.

Figure $3 \quad 319.3$ meters (Maastrichtian). Phyllosilicates and small cristobalite spherules in silty claystone. $\times 1250$.

SEM photographs, Site 208

Figure $4 \quad 431.3$ meters (Late Oligocene). Nanno chalk from the semilithified zone with some welding of grains and sheetlike structures connecting grains. X3000.

Figure 5

Detail of the central part of Figure 4. $\times 7600$.

Figure 6

460.4 meters (Late Oligocene). Nanno chalk with patch of fine crystalline calcite. $\times 1400$. 
PLATE 4
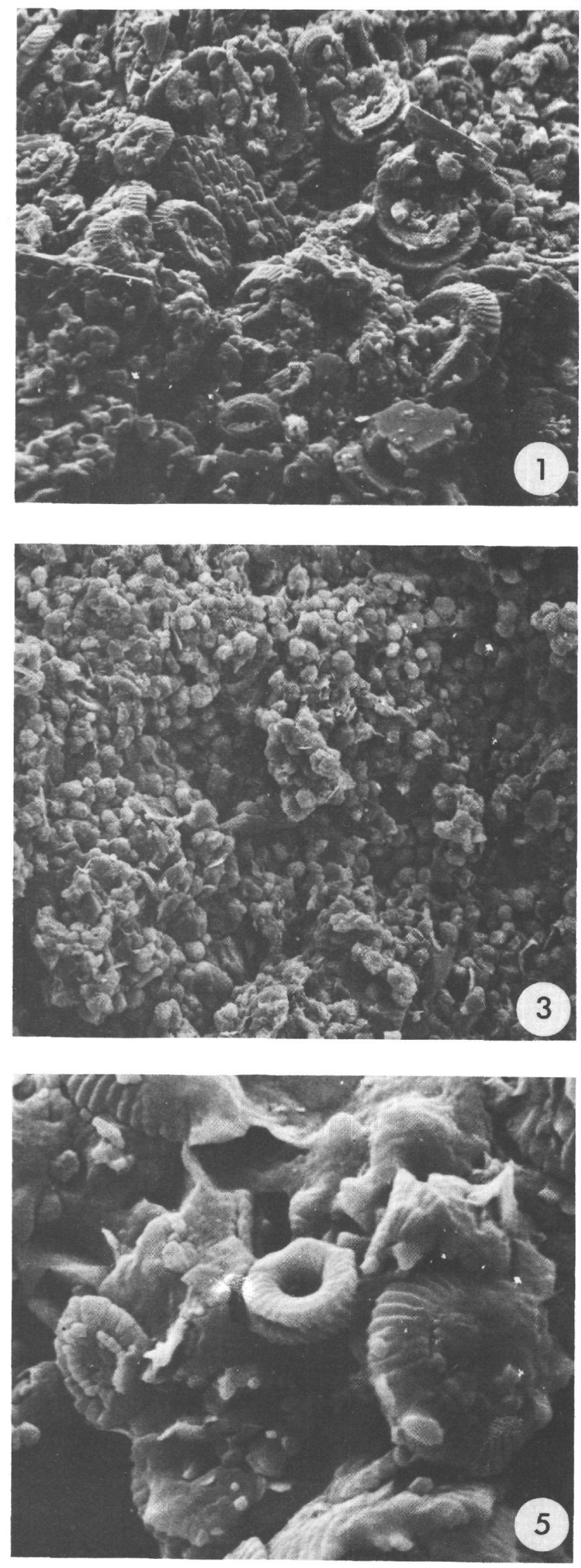
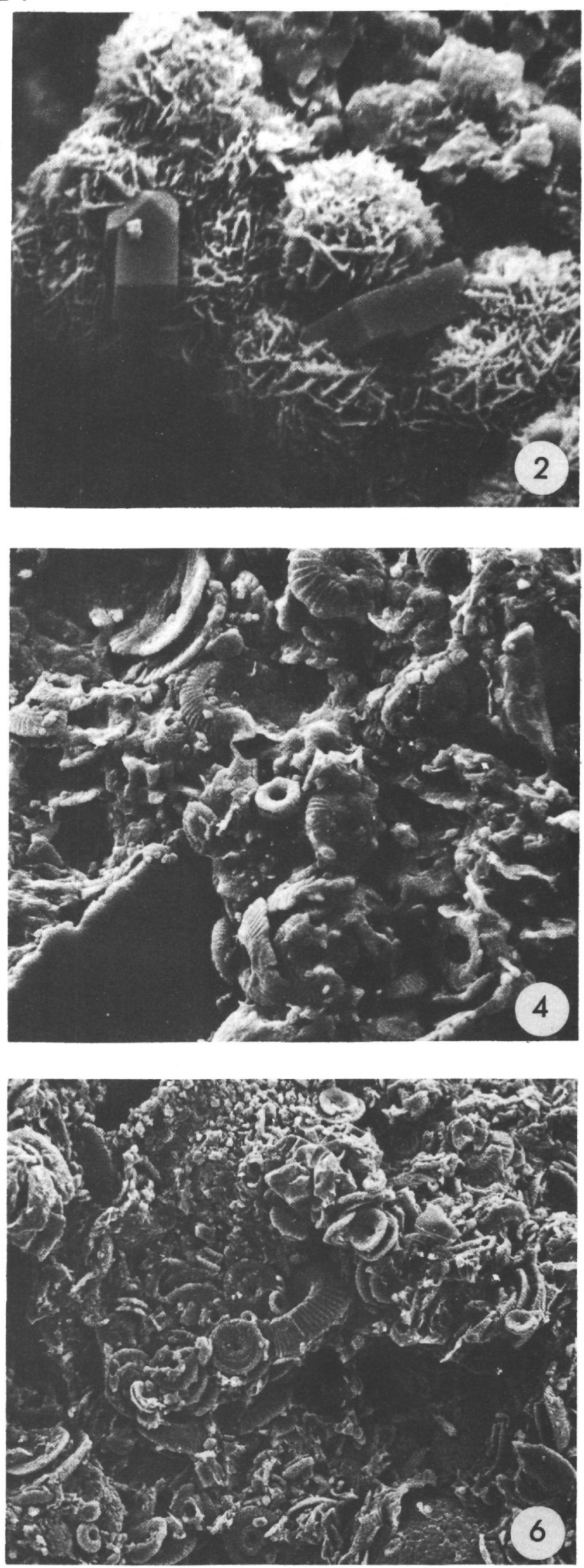
PLATE 5

SEM photographs, Site 208

Figure $1 \quad 460.4$ meters (Late Oligocene). ?Clinoptilolite crystal$s$ and a coccolith on the crystalline inner wall of a foram chamber. $\times 4400$.

Figure 2487.9 meters (Middle Eocene). Field rich in siliceous remains in rad-rich nanno chalk. Sediment has high porosity. $\times 2200$.

Figure $3 \quad 542.5$ meters (Middle Paleocene). Nanno chalk showing firm welding of grains. $\times 6900$.

Figure 4

559.3 meters (Early Paleocene). Nanno chalk with greater porosity than that in Figure 3, possible as the result of solution. $\times 2700$.

Figure $5 \quad 579.9$ meters (Late Maastrichtian). Calcic chalk with granular calcite and welding of grains. Note cristobalite spherules at left. $\times 2700$.

Figure $6 \quad 579.9$ meters (Late Maastrichtian). Calcic chalk with spherules of cristobalite. $\times 3000$. 


\section{PLATE 5}
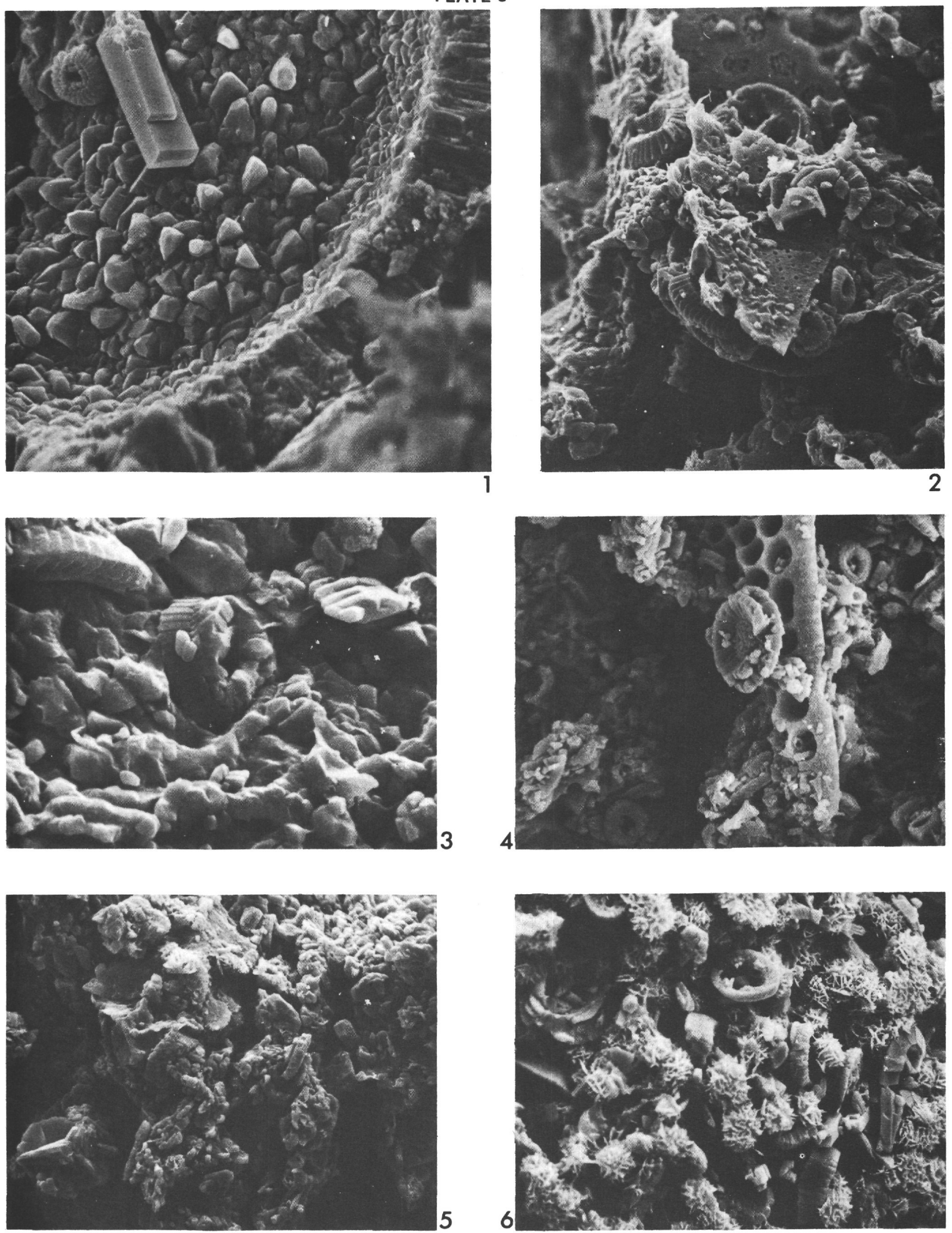
PLATE 6

SEM photographs, Site 208

Figure 1

589.4 meters (Late Maastrichtian). Calcite crystals lining a foram chamber. $\times 4300$.

Figure 2

589.4 meters (Late Maastrichtian). Calcic chalk with well preserved coccoliths, spherules of cristobalite, clinoptilalite, and ? barite. $\times 2000$.

SEM Photographs, Site 210

Figure 3441.5 meters (Late Miocene). Nanno ooze showing welding of the grains of the groundmass. $\times 2000$.

Figure $4 \quad 441.5$ meters (Late Miocene). Part of the same sample as Figure 4 showing a much more porous and less welded part. $\times 6000$.

Figure 5480.0 meters (Late-Middle Miocene). Silty clay. $\times 1000$.

Figure $6 \quad 523.6$ meters (Middle Oligocene). Nanno ooze showing proous texture and welding of grains. $\times 6000$. 
PLATE 6
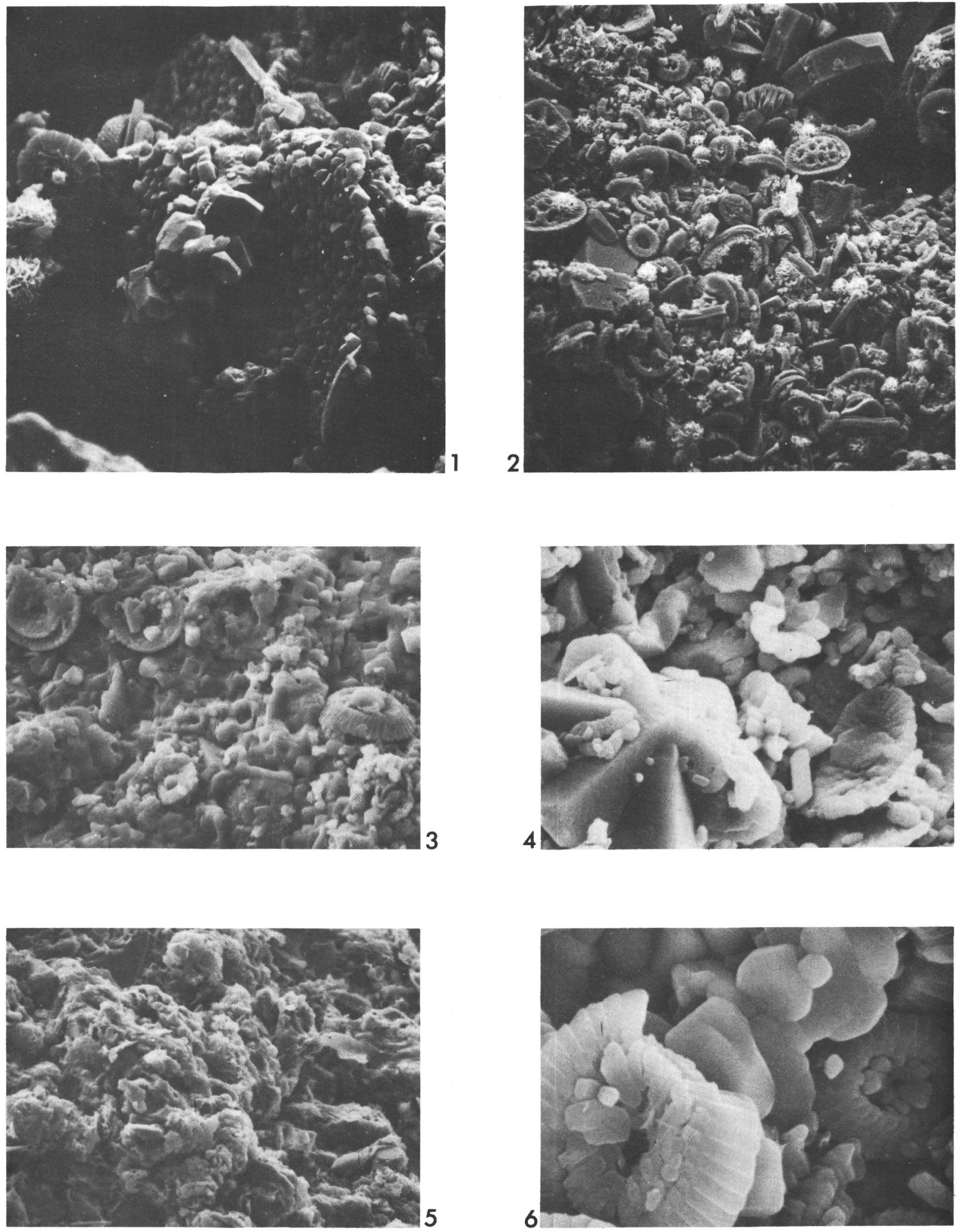
PLATE 7

SEM photographs from Site 210

Figure 15551.8 meters (Middle Eocene). Nanno chalk with strongly welded grains and granular calcite crystals. $\times 2000$.

Figure 2569.0 meters (Middle Eocene). Calcic clay with more advanced recrystallization. The large coccolith shows overgrowths and the groundmass contains flaky phyllosilicates. $\times 2000$.

Figure $3 \quad 590.5$ meters (Middle Eocene). Clay nanno chalk with irregular spherules of cristobalite. $\times 2000$.

Figure $4 \quad 653.2$ meters (Early Eocene). Nanno clay with strongly developed overgrowhts on coccoliths. $\times 2000$.

Figure $5 \quad 653.2$ meters (Early Eocene). Slickensided surface in nanno clay. $\times 1000$.

Figure 6707.8 meters (Early Eocene). Nanno clay showing the greatest degree of carbonate recrystallization found at any of the sites. $\times 2000$. 


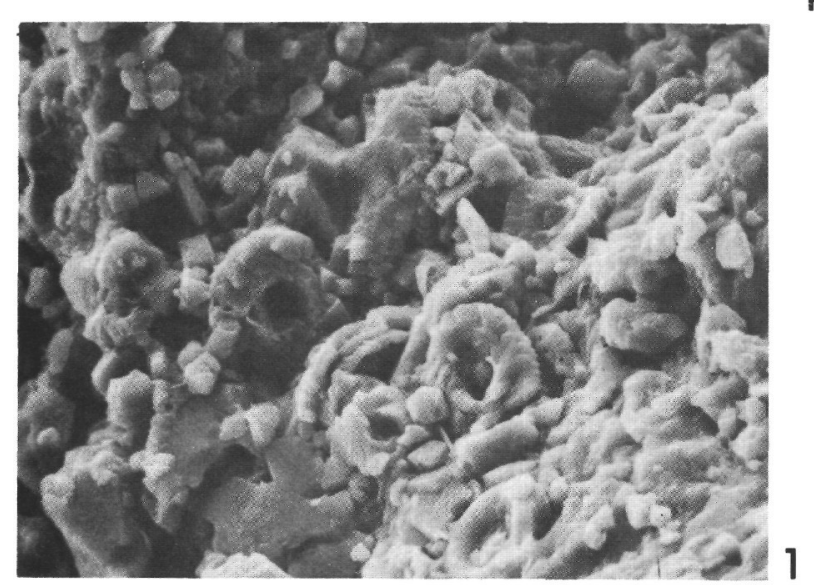

\section{PLATE 7}
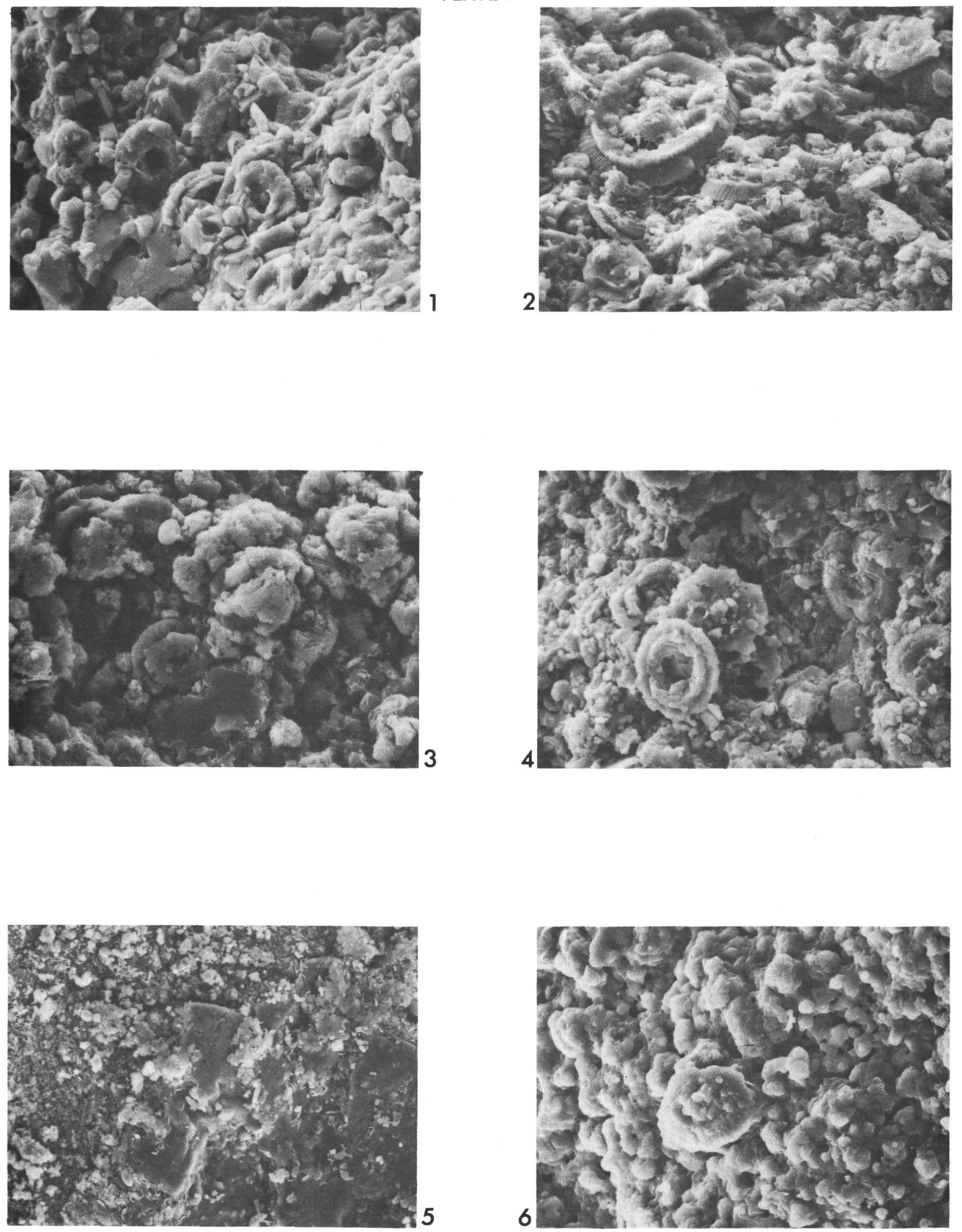